\title{
Evaluation of physiochemical parameters in hand-dug wells water in Burutu, Delta State, Nigeria
}

\author{
Esi E.O. ${ }^{1,}$, Marere S.O. ${ }^{1}$, Peretomode M. ${ }^{2}$, Asiagbe E. T ${ }^{2}$, Ohwona C. ${ }^{2}$ \\ ${ }^{1}$ Department of GNS (Physics unit), Delta State School of Marine Technology, Burutu, Delta State, Nigeria \\ ${ }^{2}$ Department of Industrial Safety and Environmental Technology, Delta State School of Marine Technology, Burutu, Delta State, Nigeria
}

\section{Email address:}

esiemmanuel@yahoo.com(Esi E.O.)

\section{To cite this article:}

Esi E.O., Marere S.O., Peretomode M., Asiagbe E. T, Ohwona C.. Evaluation of Physiochemical Parameters in Hand-Dug Wells Water in Burutu, Delta State, Nigeria. American Journal of Environmental Protection. Vol. 2, No. 6, 2013, pp. 134-140.

doi: 10.11648/j.ajep.20130206.13

\begin{abstract}
This study investigated the physiochemical parameters in hand dug wells in Burutu L.G.A. in Delta State. A total of five selected hand dug wells samples were analyzed using standard methods. The observed physiochemical parameters were colour, odour, temperature, $\mathrm{pH}$, conductivity, alkalinity, turbidity, total hardness, total dissolved solid (TDS), total suspended solid (TSS), BOD, COD, nitrate $\left(\mathrm{NO}_{5}\right)$, phosphate $\left(\mathrm{PO}_{4}^{3-}\right)$ and sulphate $\left(\mathrm{SO}_{4}^{2-}\right)$. The results of the hand dug wells water ranged concentrations are: Temperature $\left(23-25^{\circ} \mathrm{C}\right), \mathrm{pH}(5.94-7.22)$, conductivity $(45.00-1870.00$ $\mu \mathrm{s} / \mathrm{cm})$, alkalinity $(0.80-35.20)$, total hardness $(60.06-132.13 \mathrm{mg} / \mathrm{l}), \mathrm{TDS}(20.00-1140.00 \mathrm{mg} / \mathrm{l})$, TSS $(30.00-1140.00$ $\mathrm{mg} / \mathrm{l}), \mathrm{BOD}_{5}(11.52-400 \mathrm{mg} / \mathrm{l}), \mathrm{COD}(284.00-1060.00 \mathrm{mg} / \mathrm{l}), \mathrm{NO}_{3}(0.88-6.00 \mathrm{mg} / \mathrm{l}), \mathrm{PO}^{3-}{ }_{4}(0.01-2.47 \mathrm{mg} / \mathrm{l})$ and $\mathrm{SO}^{2-}{ }_{4}$ $(0.69-13.78 \mathrm{mg} / \mathrm{l})$. The high concentration of some parameters shows contamination of the hand dug well water, since they exceeded WHO standard for drinking water. This may cause some health risks on the end user. Therefore the water should be thoroughly treated before usage.
\end{abstract}

Keywords: Physiochemical Parameters, Hand Dug Well, Burutu, Delta State

\section{Introduction}

Good quality water (portable water) is defined as water that is free from diseases producing micro-organisms and chemical substances harmful to health (Iwuozor and Irabor, 2010). The use of water is an indispensable natural resource on earth. Every human being on earth needs clean and safe drinking water for use. Water is life and without it life would be non-existent. It is therefore, the desire of every individual regardless of their social or economic status to have access to clean and safe drinking water. Thus, water is an important parameter of environmental science since it is indispensable to human life. The quality of water is important in environmental studies because of its daily use for human consumption and its ability to transport pollutants. At the end of 2000 United Nations Millennium Summit, member states of which Nigeria is one adopted a set of eight (8) goals and related targets and indicators aimed at helping end to human poverty (Sachs and McArthur, 2005). Among these millennium Development Goals is a call to halve by the year 2015 the proportion of persons without sustainable access to safe drinking water and basic sanitation in developing nations.

The occurrence of pollutants in drinking water poses a serious challenge of meeting the UN target of access to safe drinking water in developing nations and also challenge of health hazard, when these radionuclides are taken to the body by ingestion (Damla et al., 2006).

Water is obtained from a number of sources; some of which are ponds, lakes, streams, underground wells, and springs. A major source of water in both rural and urban areas is groundwater (Gupta et al., 2009). In Burutu town, groundwater is the most important source of supply for domestic, drinking and other purposes. Increase necessities of increasing population have lead to the deterioration of sub-surface water (Saravanakumar and Kumar, 2011). A large percentage of the populace in developing countries die annually due to water borne diseases such as cholera, typhoid, diarrhea, etc (WHO, 2008).

The water supply for human consumption in Burutu is often directly sourced from underground water without any physical or biochemical treatment. The water used for domestic purposes should be free from toxic elements, living and non- living organisms and excessive amount of 
minerals that may be harmful to health. Groundwater through hand-dug wells can be contaminated by soil particles eroded during heavy downpours on which water impairing substances like nitrates and phosphates are washed into the wells (Taiwo et al., 2011). All the underground wells in Burutu are exposed to the air thereby making them prone to contamination from particulate matters in the air. Thus, the need to look for some useful indicators, both physical and chemical which can be used to monitor Burutu underground well water for drinking and domestic purposes arose. This result of study will provide a baseline data for future water quality monitoring.

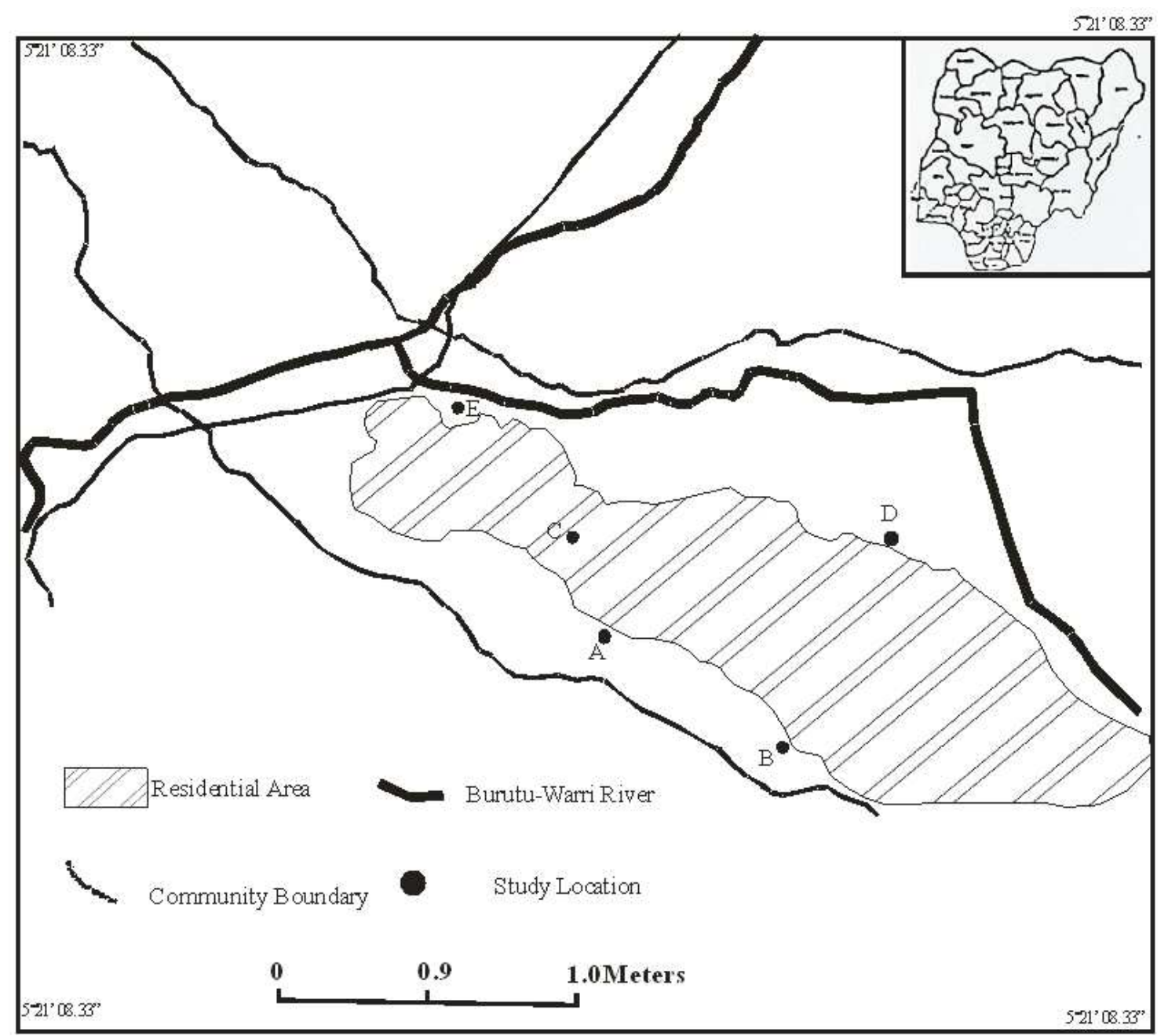

Fig1. Map of Burutu: Showing the study locations. Insert: Map of Nigeria

\section{Materials and Methods}

\subsection{The study Area}

Burutu town is an island, an ancient town and the headquarters of Burutu local government council of Delta. It lies within Longitude $5^{0} 33 \mathrm{E}$ and Latitude $5^{0} 19 \mathrm{~N}$. It is built on two sides of Forcados River, a tributary of the Niger River delta, 20 miles $(32 \mathrm{~km})$ upstream from the Bight of Benin see (figure 1). It is characterized by a hot humid climate $\left(29^{\circ} \mathrm{C}\right)$ with an average annual rainfall of $1700 \mathrm{~mm}$. It is a rural community whose main occupation is fishing and petty trading. The inhabitants of Burutu town depend mainly on hand-dug wells for their household and other domestic purpose. There is no pipe borne water in
Burutu town in Burutu Local Government Area of Delta State.

This town covers a geographical area of 3 square kilometers with a population of about 26,626 people (NPC Census, 2006).

\subsection{Sample Collection and Analysis}

Water samples were collected randomly from five (5) hand-dug wells in Burutu, Delta State using standard sample collection methods. The samples were collected in $1000 \mathrm{ml}$ plastic bottles, sealed, labeled and taken to the laboratory for analyses. The samples were subjected to various laboratory analysis using standard procedures (APHA, 1992). 


\section{3 .Results and Discussion}

Table 1: Physiochemical Parameters of Hand Dug Wells Water in Burutu Town

\begin{tabular}{|c|c|c|c|c|c|c|}
\hline S/No & Parameters & $\begin{array}{l}\text { Desomatec } \\
\text { quarters }\end{array}$ & Amber quarters & Kalaroo quarters & Chicoco quarters & $\begin{array}{l}\text { Okorodudu } \\
\text { quarters }\end{array}$ \\
\hline 1. & Colour & Not clear & Clear & Clear & Clear & Clear \\
\hline 2. & Odour & Inoffensive & Inoffensive & Inoffensive & Inoffensive & Inoffensive \\
\hline 3. & Temperature & $24^{\mathrm{O}} \mathrm{C}$ & $24^{\mathrm{O}} \mathrm{C}$ & $23^{\circ} \mathrm{C}$ & $25^{\circ} \mathrm{C}$ & $24^{\mathrm{O}} \mathrm{C}$ \\
\hline 4. & $\mathrm{pH}$ & 7.22 & 6.61 & 5.94 & 6.39 & 6.32 \\
\hline 5. & Conductivity & 1870.00 & 940.00 & 900.00 & 679.00 & 45.00 \\
\hline 6. & Alkalinity & 35.00 & 20.00 & 9.20 & 9.20 & 0.80 \\
\hline 7. & Turbidity & 0.80 & 0.40 & 0.40 & 0.40 & 0.40 \\
\hline 8. & Total Hardness & 120.12 & 132.13 & 110.11 & 80.08 & 60.06 \\
\hline 9. & TDS & 1140.00 & 680.00 & 650.00 & 580.00 & 20.00 \\
\hline 10. & TSS & 40.00 & 30.00 & 1140.00 & 80.00 & 100.00 \\
\hline 11. & $\mathrm{BOD}_{5}$ & 400.00 & 12.80 & 160.00 & 12.80 & 11.52 \\
\hline 12. & COD & 1060.00 & 156.00 & 584.00 & 548.00 & 284.00 \\
\hline 13. & $\mathrm{NO}_{3}$ & 0.88 & 3.62 & 6.00 & 2.56 & 0.88 \\
\hline 14. & $\mathrm{PO}_{3}^{-4}$ & 1.89 & 0.01 & 0.01 & 2.47 & 0.10 \\
\hline 15. & $\mathrm{SO}_{2}^{-4}$ & 13.78 & 0.69 & 13.78 & 1.38 & 0.69 \\
\hline
\end{tabular}

Table 2: Comparison of mean concentrations of values hand-dug wells values with WHO standard

\begin{tabular}{|c|c|c|c|c|c|c|}
\hline S/No & Parameters & Min & $\operatorname{Max}$ & Mean & $\begin{array}{l}\text { WHO } \\
2007 \\
\end{array}$ & Standard \\
\hline 1. & Colour & Clear & Clear & Clear & Clear & \\
\hline 2. & Odour & inoffensive & Inoffensive & Inoffensive & 5 unit & \\
\hline 3. & Temperature & $23^{\circ} \mathrm{C}$ & $25^{\circ} \mathrm{C}$ & $24^{\mathrm{O}} \mathrm{C}$ & - & \\
\hline 4. & $\mathrm{Ph}$ & 5.94 & 7.22 & 6.40 & $6.50-8.5$ & \\
\hline 5. & Conductivity & 45.00 & 1870.00 & 886.80 & 250 & \\
\hline 6. & Alkalinity & 0.80 & 35.20 & 30.72 & 500 & \\
\hline 7. & Turbidity & 0.40 & 0.80 & 0.54 & 25.00 & \\
\hline 8. & Total Hardness & 60.06 & 132.13 & 100.50 & 500 & \\
\hline 9. & TDS & 20.00 & 1140.00 & 614.00 & 500 & \\
\hline 10. & TSS & 30.00 & 1140.00 & 278.00 & 500 & \\
\hline 11. & $\mathrm{BOD}_{5}$ & 11.52 & 400.00 & 119.42 & $0.1-2$ & \\
\hline 12. & COD & 284.00 & 1060.00 & 335.6 & - & \\
\hline 13. & $\mathrm{NO}_{-3}$ & 0.88 & 6.00 & 2.79 & - & \\
\hline 14. & $\mathrm{PO}_{3}^{-4}$ & 0.01 & 2.47 & 2.88 & - & \\
\hline 15. & $\mathrm{SO}_{2}^{-4}$ & 0.69 & 13.78 & 6.06 & 20 & \\
\hline
\end{tabular}

WHO, 2003*; WHO, 2004** Guideline.

Table 1 and 2 shows the values of various physiochemical parameters determined from the sampled hand dug wells of various location and minimum, maximum and mean values in Burutu town in Burutu Local Government Area of Delta State, Nigeria.

Geological speaking, the colouration of Desomatech 
quarters sample was due to sedimentation of the environment over the years. This is because of decomposition of biological materials in the subsurface sample. Temperature has been known to have effects on other parameters like dissolved oxygen and also toxicity of metals (Awofolu et al., 2007). The temperatures are lower than the commission of European Community (1988) maximum standard for temperature for drinking water of $25^{\mathrm{O}} \mathrm{C}$, except sample from Chicoco quarters with temperature of $25^{\circ} \mathrm{C}$. The colour of sampled wells water are clear except sample from Desomatech quarters which is not clear and this can be attributed to depth of the well and the run-off water. The sampled wells are all inoffensive.

The $\mathrm{pH}$ of the sampled hand dug wells water ranged from 5.94 - 7.22 with mean value of 6.40 . WHO $\mathrm{pH}$ standard for drinking water is 6.5 - 8.5 (WHO, 2007). When compared, the $\mathrm{pH}$ values of the hand dug wells of Desomatech and Amber quarters falls within the WHO standard for drinking water, but Kalaroo quarters, Chicoco quarters and Okorodudu quarters are lower than the WHO standard as showed in fig. 2 , it indicate that these wells are acidic in nature and this may be attributed to acidic nature of the soil composition and the acid rain due to gas flaring in the study area. The $\mathrm{pH}$ of water may affect the solubility and bioavailability of other substances in water (EPA, 2003).

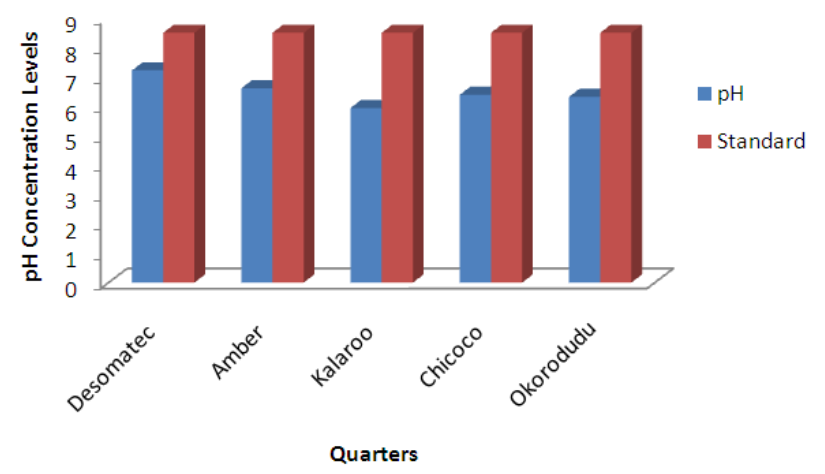

Fig. 2: Comparison of $p H$ concentration levels with standard.

Conductivity of water is a measure of total salt content in water (Morrison et al., 2001). The conductivity concentration values of the hand dug wells water ranged from $45.00 \mu \mathrm{s} / \mathrm{cm}-1870.00 \mu \mathrm{s} / \mathrm{cm}$ with mean value of $886.80 \mu \mathrm{s} / \mathrm{cm}$. In drinking water, WHO standard for conductivity is $250 \mu \mathrm{s} / \mathrm{cm}$ (WHO, 2003). When compared, the conductivity obtained results are all higher than the WHO standard except Okorodudu quarters with obtained values of $45.00 \mu \mathrm{s} / \mathrm{cm}$ as showed in fig. 3 . These high conductivity concentration values can affect both human and aquatic life negatively in the community. The alkanity concentration values ranged from $0.80 \mathrm{mg} / 1-35.20 \mathrm{mg} / \mathrm{l}$ with mean value of $30.72 \mathrm{mg} / \mathrm{l}$. When these obtained results are compared with WHO permissible standard limit value of $500 \mathrm{mg} / \mathrm{l}$, the obtained result falls within the WHO standard limit for drinking water as showed in fig.4.

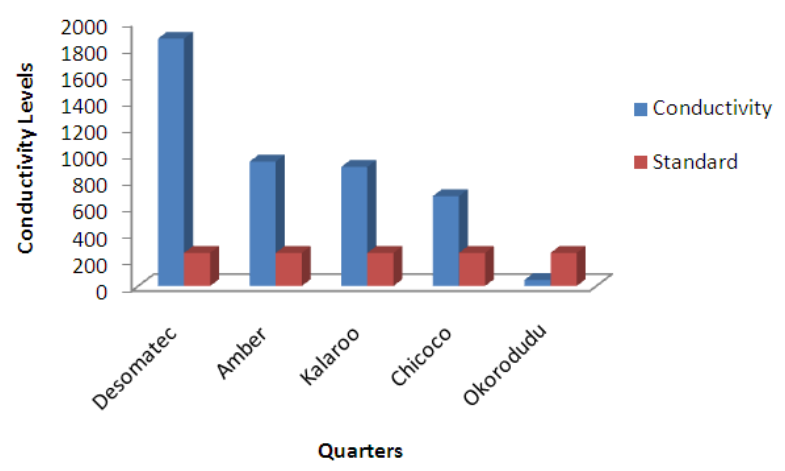

Fig. 3: Comparison of conductivity concentration levels with standard.

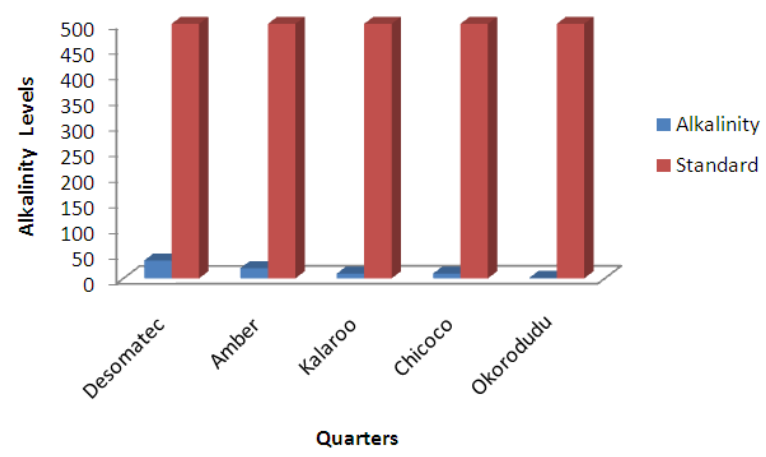

Fig. 4: Comparison of alkalinity concentration levels with standard.

Total Hardness of water is usually due to the presence of multivalent metal ions, which come from minerals dissolved in the water (Taiwo et al., 2011). Water hardness standard for drinking water is $10-500 \mathrm{mg} / \mathrm{l}$ (Marier et al., 1979; WHO, 2007). The general accepted classification of hardness in drinking water in terms of Calcium carbonate $\left(\mathrm{CaCO}_{3}\right)$ are as followed $0-7 \mathrm{mg} / \mathrm{l}$ as soft, $75 \mathrm{mg} / \mathrm{l}-150$ $\mathrm{mg} / \mathrm{l}$ as moderately hard and $150 \mathrm{mg} / \mathrm{l}$ and above as hard water (Nduka and Orisakwe,). Based on these three classifications of water hardness, the obtained results that ranged from $60.06 \mathrm{mg} / \mathrm{l}-132.13 \mathrm{mg} / \mathrm{l}$ with mean value of $100.50 \mathrm{mg} / \mathrm{l}$ can be interpreted as follows: Okorodudu quarters as soft water, Desomatech quarter, Amber quarters, Kalaroo quarters and Chicoco quarters as moderate hard water. Also all the samples are below WHO standard acceptance limit for drinking water as shown in fig.6. Hardness does not pose significant health effect on human.

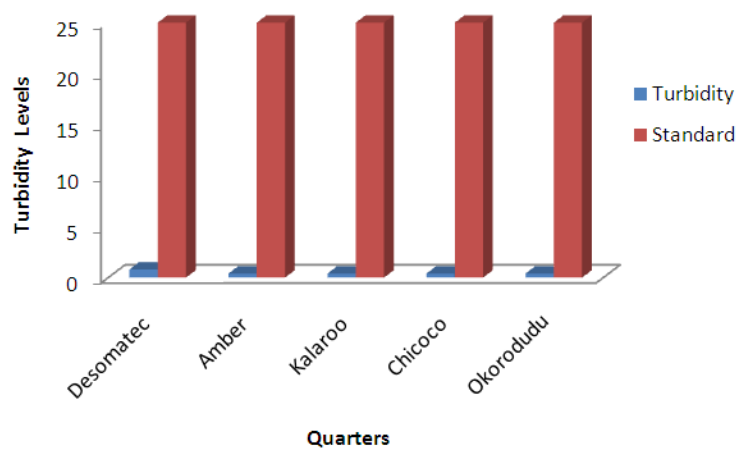

Fig. 5: Comparison of turbidity concentration levels with standard. 


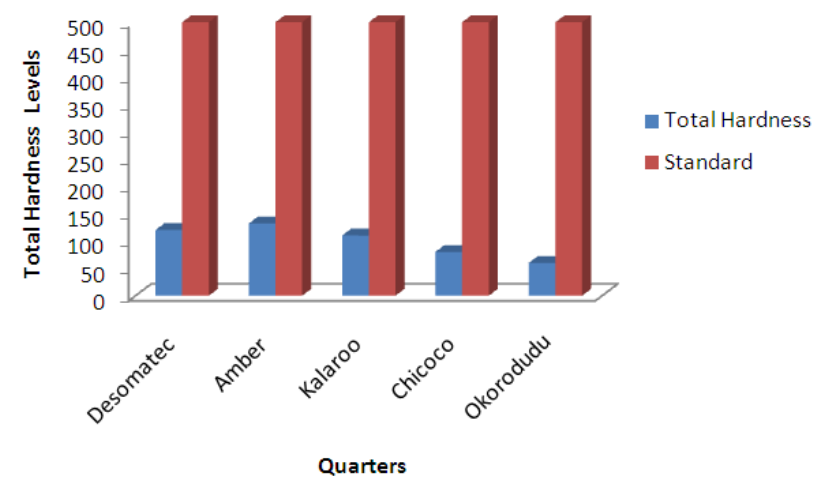

Fig. 6: Comparison of total hardness concentration levels with standard.

The total dissolved solid (TDS) values of the hand dug wells water sampled ranged from $20.00 \mathrm{mg} / \mathrm{l}-1140.00$ $\mathrm{mg} / \mathrm{l}$ with mean value of $614.00 \mathrm{mg} / \mathrm{l}$. WHO standard for drinking water is $500 \mathrm{mg} / \mathrm{l}$ (WHO, 2007). When compared the obtained results values with that of WHO standard shows that TDS values for Desomatech quarter, Amber quarters, Kalaroo quarters and Chicoco quarters are all higher than the WHO standard permissible limit, except Okorodudu quarters which is below the WHO standard as shown in fig.7. The high concentration of TDS could results into corrosions.

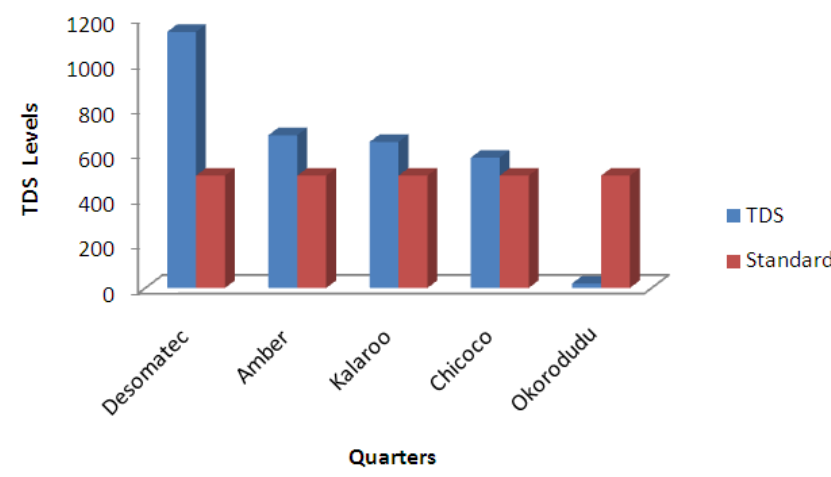

Fig. 7: Comparison of TDS concentration levels with standard.

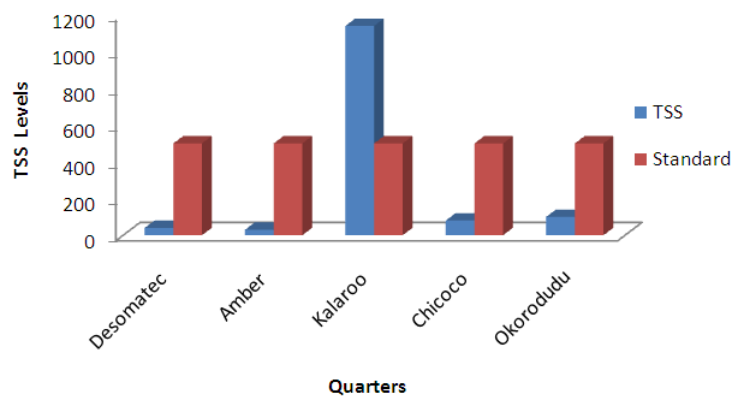

Fig. 8: Comparison of TSS concentration levels with standard.

The total suspended solid (TSS) concentration values ranged from $30.00 \mathrm{mg} / 1-1140.00 \mathrm{mg} / \mathrm{l}$ with mean value of $278.00 \mathrm{mg} / \mathrm{l}$. In drinking water, WHO standard for TSS is $500 \mathrm{mg} / \mathrm{l}$ (WHO, 2007). When compared, the TSS obtained results are all lower than the standard permissible limit of drinking water except Kalaroo quarters which has obtained value of $1140.00 \mathrm{mg} / \mathrm{l}$ as shown in fig.8. The high concentration of TSS in Kalaroo quarters can be attributed to run-off water. The high TSS in this well could be dangerous to human health hence it is not advisable for consumption without proper filtering and treatment.

Biochemical oxygen demand $\left(\mathrm{BOD}_{5}\right)$ is the measurement of the dissolved oxygen used by microorganisms in the biological oxidation of organic matter (Obot et al., 2008). A high BOD therefore indicates the presence of large amount of organic pollution caused by microbial organisms in water (Villa-Elena, 2006). The concentrations of BOD ranged from $11.52 \mathrm{mg} / 1$ - $400 \mathrm{mg} / \mathrm{l}$ with mean value of $119.42 \mathrm{mg} / \mathrm{l}$. WHO standard for drinking water ranged from 0.1-2 $\mathrm{mg} / \mathrm{l}$ (WHO, 2004). When compared, the BOD obtained values from all the wells are all higher than the WHO standard permissible limit for drinking water as shown in fig.9.

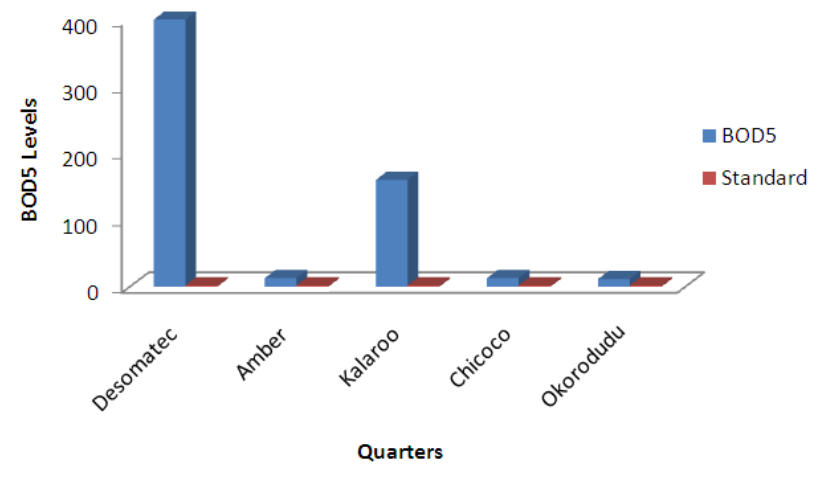

Fig. 9: Comparison of $\mathrm{BOD}_{5}$ concentration levels with standard.

The chemical oxygen demand (COD) concentration values ranged from $284.00 \mathrm{mg} / \mathrm{l}-1060.00 \mathrm{mg} / \mathrm{l}$ with mean values of $335.6 \mathrm{mg} / \mathrm{l}$. These obtained results when compared with FEPA standard guideline with value $40 \mathrm{mg} / 1$ (FEPA, 1991), it shows that all the well water results are above the FEPA standard.

Nitrate $\left(\mathrm{NO}^{3-}\right)$, the most highly oxidized form of Nitrogen compounds is commonly present in surface and groundwater because it is the end product of the aerobic decomposition of organic nitrogenous matter (Akinbile and Yusoff, 2011). Nitrate has its values ranged from $0.88 \mathrm{mg} / \mathrm{l}-$ $6.00 \mathrm{mg} / \mathrm{l}$ with mean value of $2.79 \mathrm{mg} / \mathrm{l}$. Comparing these obtained results with WHO standard maximum limit of 10 $\mathrm{mg} / \mathrm{l}$ (WHO, 2003), it shows that nitrate in all the wells falls below WHO standard, hence it does not impose significant health problem on both animal and human. Nitrate in water is dangerous to human health when it is either equal to or above $10 \mathrm{mg} / \mathrm{l}$ concentration as it causes a condition known as methemoglobinemia or blue body disease in infants under the age of three to six months. Other aliments associated with high nitrate concentration are diarrhea and respiratory diseases (Ward et al., 2005). It has been suggested that long term exposure to drinking water, nitrate at levels below the maximum contaminant level $(10 \mathrm{mg} / \mathrm{l})$ is not associated with pancreatic cancer, but high levels of nitrate and nitrosamines in drinking water 
have be associated with increased mortality, cancer and lesions (Nduka and Orisakwe, 2009).

Phosphate is toxic to both animals and humans at extremely high levels and could cause digestive problems (D, Amelio, 2007). Phosphate results obtained ranged from $0.01 \mathrm{mg} / \mathrm{l}-2.47 \mathrm{mg} / 1$ with mean value of $2.88 \mathrm{mg} / 1$, which does not exceed the WHO standard stipulated tolerance level of $5.0 \mathrm{mg} / \mathrm{l}$ for drinking water when compared (Long and Balogun, 2010).

The concentration of sulphates in the hand dug wells ranged from $0.69 \mathrm{mg} / \mathrm{l}-13.78 \mathrm{mg} / \mathrm{l}$ with mean value of $6.06 \mathrm{mg} / \mathrm{l}$. WHO sulphate standard for drinking water is $20.00 \mathrm{mg} / \mathrm{l}$ (WHO, 2007). When compared the WHO standard with the obtained results, it shows that all the wells obtained result falls below the WHO standard as shown in fig. 10.

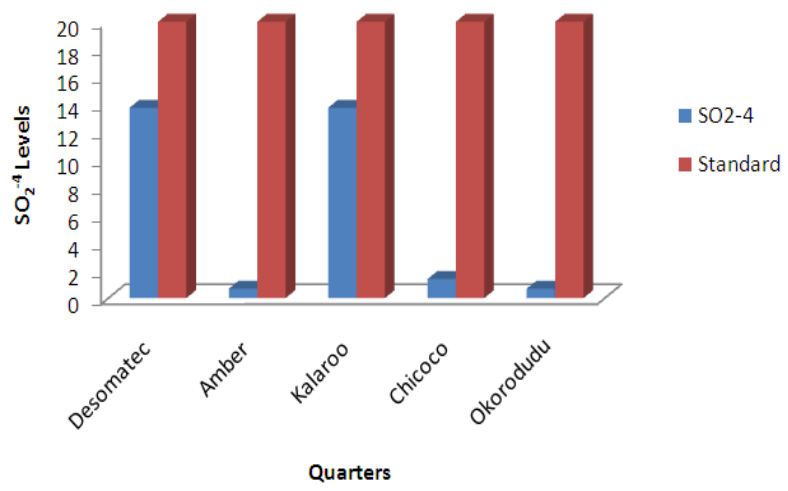

Fig. 10: Comparison of $\mathrm{SO}_{2}^{-4}$ concentration levels with standard.

\section{Conclusion}

This study has shown that physiochemical parameters in Burutu Community hand dug wells water generally contain high concentrations of pollutants except the concentration of the physiochemical parameters (temperature, alkalinity, turbidity and $\mathrm{PO}_{4}^{3-}$ ) which are within the standard permissible limit. These can be attributed to run-off water, water intrusion from the sea and gas flaring contaminated rain water due to gas flaring around the community that enter into the hand dug wells. However, the results indicated dangerous health effect to both human and animals if the surrounding hand dug wells water are used for domestic purposes. As a result of the high concentrations of physiochemical contamination of water from the hand dug wells, health problem such as such as typhoid fever, cholera, diarrhea, hepatitis, worm infestation etc. are imminent when such water is consumed in its present state.

In Nigeria, borehole water supply is regarded as safe drinking water as most middle class of socio-economic strata rely on this source of water supply. Hence Government should undertake a proper groundwater exploration project in Burutu community and provide well treated borehole water for residents of the community.

\section{References}

[1] APHA, 1992. Standard for the examination of Wastewater $18^{\text {th }}$ Edition Washington D.C. American Public Health Association.

[2] Awofulu, OR., Dupleiss, R. and Rampedi, I. 2007. Influence of discharge Effluent on Water Quality of surface Water utilized for Agricultural Purposes. African Journal of Biotechnology. 6:2251-2258.

[3] Damla, N., Cevik, U., Karahan, G., and Kobya, A.I. (2006). Gross alpha and beta activities in tap water in eastern black sea region of turkey. Chemosphere vol. 62(37). p957-960.

[4] D'Amello, S. 2007. Preliminary water quality at Springbank Dam, Thames River. Trout Unlimited Canada: Ontario, Canada. No. ON-020. 7 - 11 .

[5] EPA. 2003. "Drinking Water Infrastructural Needs Survey". www.eoa.gov.safetywater/needssurvey/pdf2003. Factsheet 816F05014.

[6] Iwuozor, C. and Ilabor, SC. 2010. Physiochemical and Microbial Analysis of Water Samples Collected from Anwai Stream in Oshimili- South Local government Area, Asaba, Delta State, Nigeria. Contemporary Journal of Educational Research. Vol 1:172-181.

[7] Marier, JR., Neri, LC and Anderson, TW. 1979. Water Hardness, Human Health, and the Importance of Magnesium. National Research council of Canada: Ottawa, Canada.

[8] Morrison, G., Fatoki, OS and Ekberg, A. 2001. Assessment of the Impact of Point Source Pollution from Keikammahoek Sewage Treatment Plant on the Keikamma River-pH, Electrical Conductivity, Oxygen Demanding Substance (COD) and Nutrients". Water.SA.27:475-480.

[9] Obot, IB., Israel, AU., Umaren, SA., Mkpenie, V. and Ebong, GA. 2008. Effluents and Solid Water analysis in a petrochemical company- A Case Study of Eleme Petrochemical Company Ltd, Portharcourt, Nigeria. EJournal of Chemistry. Vol 5(1). $74-80$.

[10] Sachs, JD. and McArthur, JW. 2005. The Millennium Project: a plan for meeting the millennium development goals. The lancet 365 .

[11] SaravanaKumar, K. and Ranjith Kumar, R. 2011. Analysis of water quality parameters of ground water near Ambattur Industrial area, Tamil Nadu, India. India Journal of Science and Technology. 4(5): $660-662$.

[12] Taiwo, AM., Adeogun, AO., Olatunde, KA. and Adegbite, KI. 2011. Analysis of Groundwater Quality of Hand-Dug wells in Peri-Urban Area of Obantoko, Abeokuta, Nigeria for selected Physio-Chemical Parameters. Pacific Journal of science and Technology. 12(1):527-534.

[13] Villa-Elena, S. 2006. Parkinson's disease and exposure to manganese during welding. Tech. J welding Allied Process. 2(5): 106-110.

[14] Ward, MH., Dekok, TM., Levallois, P., Brender, J., Gulis, G. and Nolan, BT. 2005. Workgroup Report Drinking water Nitrate and Health-Recent Findings and Research Needs. Environ Health Perspect. 113:1607-1614. 
[15] WHO. 2003. Algae and Cyanobacter in Fresh water. In: Guidelines for Safe Recreational Water Environments. Vol 1: Coastal and Freshwaters. World Health Organization: Geneva, Switzerland.136-138.
[16] WHO. 2008. Safe water and Global Health. www.who/int/features/qa/70/en/index.htm. 